\title{
"Enabling stock market development in Africa: A review of the macroeconomic drivers"
}

\begin{tabular}{|c|c|}
\hline \multirow{4}{*}{ AUTHORS } & $\begin{array}{l}\text { Paul Uzum } \\
\text { Ailemen Ochei lkpefan (D) https://orcid.org/0000-0003-0532-4234 }\end{array}$ \\
\hline & Alexander Ehimare Omankhanlen (D) https://orcid.org/0000-0002-4004-4046 \\
\hline & Jeremiah Ogaga Ejemeyovwi (D https://orcid.org/0000-0002-6856-1387 \\
\hline & Benjamin Ighodalo Ehikioya (D https://orcid.org/0000-0003-3824-3609 \\
\hline ARTICLE INFO & $\begin{array}{l}\text { Paul Uzum, Ailemen Ochei Ikpefan, Alexander Ehimare Omankhanlen, Jeremiah } \\
\text { Ogaga Ejemeyovwi and Benjamin Ighodalo Ehikioya (2021). Enabling stock } \\
\text { market development in Africa: A review of the macroeconomic drivers. Investment } \\
\text { Management and Financial Innovations, 18(1), 357-364. } \\
\text { doi:10.21511/imfi.18(1).2021.29 }\end{array}$ \\
\hline DOI & http://dx.doi.org/10.21511/imfi.18(1).2021.29 \\
\hline RELEASED ON & Tuesday, 30 March 2021 \\
\hline RECEIVED ON & Monday, 23 November 2020 \\
\hline \multirow[t]{2}{*}{ ACCEPTED ON } & Wednesday, 03 February 2021 \\
\hline & $((c)$ EY \\
\hline LICENSE & $\begin{array}{l}\text { This work is licensed under a Creative Commons Attribution } 4.0 \text { International } \\
\text { License }\end{array}$ \\
\hline JOURNAL & "Investment Management and Financial Innovations" \\
\hline ISSN PRINT & $1810-4967$ \\
\hline ISSN ONLINE & $1812-9358$ \\
\hline PUBLISHER & LLC "Consulting Publishing Company "Business Perspectives" \\
\hline FOUNDER & LLC "Consulting Publishing Company "Business Perspectives" \\
\hline
\end{tabular}

NUMBER OF REFERENCES

21

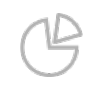

NUMBER OF FIGURES

0

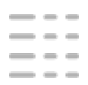

NUMBER OF TABLES

2

(C) The author(s) 2021. This publication is an open access article. 


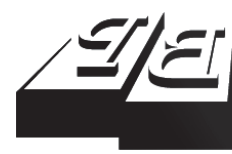

BUSINESS PERSPECTIVES

(O)

LLC "CPC "Business Perspectives"

Hryhorii Skovoroda lane, 10,

Sumy, 40022, Ukraine

www.businessperspectives.org
Received on: $23^{\text {rd }}$ of November, 2020 Accepted on: $3^{\text {rd }}$ of February, 2021 Published on: $30^{\text {th }}$ of March, 2021

(c) Paul Uzum, Ailemen Ochei Ikpefan, Alexander Ehimare Omankhanlen, Jeremiah Ogaga Ejemeyovwi, Benjamin Ighodalo Ehikioya, 2021

Paul Uzum, M.Sc. (Finance), College of Management and Social Sciences, Banking and Finance Department, Covenant University, Nigeria.

Ailemen Ochei Ikpefan, Ph.D. (Finance), Professor, College of Management and Social Sciences, Banking and Finance Department, Covenant University, Nigeria.

Alexander Ehimare Omankhanlen, Ph.D. (Banking and Finance), Senior Lecturer, College of Management and Social Sciences, Banking and Finance Department, Covenant University, Nigeria.

Jeremiah Ogaga Ejemeyovwi, Ph.D. (Economics), Lecturer, College of Management and Social Sciences Economics and Development Studies Department, Covenant University, Nigeria. (Corresponding author)

Benjamin Ighodalo Ehikioya, Lecturer, College of Management and Social Sciences, Banking and Finance Department, Covenant University, Nigeria.

This is an Open Access article, distributed under the terms of the Creative Commons Attribution 4.0 International license, which permits unrestricted re-use, distribution, and reproduction in any medium, provided the original work is properly cited.

Conflict of interest statement: Author(s) reported no conflict of interest
Paul Uzum (Nigeria), Ailemen Ochei Ikpefan (Nigeria),

Alexander Ehimare Omankhanlen (Nigeria), Jeremiah Ogaga Ejemeyovwi (Nigeria), Benjamin Ighodalo Ehikioya (Nigeria)

\section{ENABLING STOCK MARKET DEVELOPMENT IN AFRICA: A REVIEW OF THE MACROECONOMIC DRIVERS}

\begin{abstract}
Africa has underdeveloped stock markets that have failed to meet the continent's capital needs, such as rapid economic growth. This research analyzes the key drivers of stock market development in Africa from a macroeconomic perspective. The study examines several macroeconomic variables, including credit to the private sector, foreign direct investment, external reserves, money supply, external trade, per capita GDP, inflation, and lending rate to explain stock market development in Africa. The study builds a panel data consisting of eight African countries from 1994 to 2018 and applies the pooled mean group estimation technique. The analysis shows that in the long run, credit to the private sector, external reserves, and inflation are the most important factors that influence stock market development, while in the short run, income and trade openness are significant in explaining stock market development in Africa. The study recommends that policies to develop African stock markets should center on developing the private sector through access to credit, increased per capita income, and effective foreign reserve management to boost local and foreign investors' confidence.
\end{abstract}

\section{Keywords}

private sector credit, African stock markets, trade openness, external reserve, per capita GDP, money supply, lending rate

\section{JEL Classification}

A11, D53, E44, G15

\section{INTRODUCTION}

Stock market development is shaped by events in the macroeconomic environment in which it is domiciled. This nexus explains why the most developed and efficient stock markets are found in the world's most industrialized countries. For example, the biggest stock markets are in the world's leading economies - the United States and China - with a stock market capitalization of USD 32.1 trillion and USD 8.7 trillion, respectively, as of the end of 2017 (World Bank, 2020). Apart from having a large economy, industrialized countries are characterized by macroeconomic stability with minimal inflation, moderate interest rate, and stable exchange rate; they also have a thriving private sector. Economic growth and per capita income are two closely related issues that account for the level of stock market development in a country. A high rate of economic growth brings economic prosperity, which encourages an increase in the number of individuals willing to invest in stocks, just like a rise in per capita income in a country, which increases people's ability to save or invest (Bello et al., 2020). Innovations in monetary and fiscal policy, exchange rate, income distribution, inflation, trade balances, and even crude oil prices have consequences for stock market development. Again, the size of the economy and the macroeconomic structure are also important factors. 
Stock market development may be visualized from varied standpoints. The development refers to an increase in the market capitalization, stock market index, the number of listed businesses, level of market liquidity, listed entities' performance, level of participation among local and foreign investors, and reduction in market concentration. On average, a nation's equity market indicates the health of that economy. The trend may help explain the past, understand the present, and predict the future economic trend. While economic fundamentals influence the performance of equity markets, the equity market, in turn, provides a feedback mechanism to policy formulators on the perception of investors on the trend in economic activities. Thus, governments must keep a close eye on equity market activities and build a favorable stock market environment to thrive.

On one hand, international investors always need confidence that their funds and income can be repatriated at will, and a problem may arise for the host nation when there is a mass exodus of foreign capital due to exogenous shocks outside the control of the country. On the other hand, stock markets also require a sound banking system to support their development as listed companies perform better in countries where credits are readily available (Ejemeyovwi et al., 2019). When credits are readily available, margin lending and security lending activity increase, boosting stock market liquidity. However, the African macroeconomic environments exhibit unique trends that almost always conflict with economic theory. Hence, the question of whether the African macroeconomic environment significantly influences the stock market performance and the magnitude of impact needs to be investigated. This study embarks on this inquiry to ensure answers are provided to answer the raised overarching analytical questions.

\section{LITERATURE REVIEW}

Several studies have been carried out in various countries on the relationship between economic variables and development in the stock market. Tsaurai (2018) examined the drivers of equity market development in developing stock markets. $\mathrm{He}$ used the pooled ordinary least square, the fixed and random effects methodology; the significant factors influencing stock market development were economic growth, foreign direct investment, and infrastructure development. Other factors were exchange rates, price level (inflation), savings, trade openness, a developed banking system, and liquidity levels in the market. On a related note, Mroua and Trabelsi (2019) probed the relationship between exchange rates and equity market indices in BRICS nations using the Generalized Method of Moments (GMM) regression technique. The research findings were that changes in the exchange rate is a vital factor in explaining both the previous and present volatility of the equity market index in BRICS nations.

Kabuga (2018) examined the connection between fiscal deficit and stock market performance in eight African countries. The findings provided evidence of long-run cointegration between budget deficits and stock prices. The study also found that budget deficits depress stock market performance in the short run but directly affect stock market performance in the long run. Also, Agyapong and Badjabeng (2018) examined how foreign direct investment and external debt influence financial sector growth in Africa, using the Generalized Method of Moments estimation technique. The results showed that foreign direct investment and external debt directly correlate with financial sector growth in Africa.

Khan (2017) examined the economic drivers of stock market development in South Asian countries. Using the ARDL bound test technique, the empirical findings were that inflation and exchange rate are positively related to stock returns in China. Simultaneously, an inverse relationship was observed between the interest rate and the returns on equities. Similarly, Jamaludin, Ismail, and Manaf (2017) investigated the relationship between economic variables and equity market returns in ASEAN countries (Singapore, Malaysia, and Indonesia). Using the panel least squares regression analysis, inflation and exchange rate influence stock market returns. Simultaneously, the money supply is not an essential factor in explaining the stock market return. The study concludes 
that inflation is inversely related to stock market returns, and the effect is greater than that of the exchange rate.

Rasiah, Habibullah, and Hamid (2017) examined the relationship between equity market returns and its key determinants, including income, inflation, and happiness, on selected OECD countries with data ranging from 1973 to 2012. Based on the dynamic heterogeneous panel estimation techniques, the empirical findings were that income directly affects the returns on equities, inflation inhibits stock market returns, and happiness is not an essential factor in explaining stock returns. Matadeen (2017) explores the economic factors that account for stock market development in 14 Sub-Saharan African countries. Based on the panel vector error correction model, the result indicated that a developed banking sector, economic growth, liquidity in the equity market, investment level, and stable economic conditions are principal drivers of equity market development in SubSaharan Africa. More so, the rate of savings was found to have a negative implication for the growth of equity markets for Sub-Saharan African countries. In the short run, economic growth indirectly stimulates stock market development.

Balogun, Dahalan, and Hassan (2016) studied the effect of market liberalization and financial growth on equity market development in seven Sub-Saharan African countries. Using dynamic heterogeneous pooled mean group estimation technique, the empirical findings revealed that stock market liberalization has a positive longterm effect on the economies of the selected countries; more so, financial sector growth also has a significant positive long-term impact on the development of stock markets. The macroeconomic determinant of stock market growth in Turkey was examined by Bayar (2016). Using the ARDL bound test, the results showed that economic growth and liquidity level in the market had positive effects. In contrast, inflation had a negative impact on the development of the stock market in Turkey.

Conclusively, given the empirical evidence and trends in the literature, very few studies examined the possible interaction between stock market determinants and macroeconomic variables such as credit to the private sector, per capita GDP, infla- tion, external reserve, broad money, lending interest rate, and trade openness. Extending the study by Balogun, Dahalan, and Hassan (2016), this study breaks out from the norm to uniquely determine the significant influencers of stock market development in eight selected countries in Africa that represent over 97 percent of the equity in the African stock market and represent the various regions in Africa. The study also contributes to the existing gap by adopting the panel data framework and using the pooled mean group technique of estimation, appropriate for handling related issues in literature.

\section{ECONOMETRIC METHODOLOGY AND DATA}

This study adopts the Calderon-Rossell (1990) stock market model, which expresses stock market growth as a function of economic factors. Since this study focuses on the macroeconomic dimension of stock market development, the model to be estimated is specified as follows:

$$
Y_{i t}=\alpha_{i}+\delta Y_{i t-1}+\beta M_{i t}+\varepsilon_{i t} \text {, }
$$

where $Y$ represents the market capitalization of the stock exchange; $\alpha_{i}$ represents the unobserved country-specific fixed effect; $\varepsilon_{i t}$ is the white noise error term; $M$ is an array of macroeconomic variables comprising per capita GDP, private sector credit, external reserve, inflation, foreign direct investment, lending interest rate, broad money supply, and external trade.

Following the pattern of Balogun, Dahalan, and Hassan (2016), the study utilizes the pooled mean group (PMG) estimation technique for dynamic heterogeneous panels from Pesaran, Shin, and Smith (1999) to study the homogeneity of the long-run coefficients; and the heterogeneity of the short-run parameters and the speed of adjustment (error correction term). The PMG estimator's assumptions are the following: first, there is no serial correlation among the error terms as they are randomly distributed and are independent of the regressors; this implies that the independent variables are assumed to be exogenous. Secondly, long- 
term relationships exist between the explained variable and the explanatory variables. Thirdly, the long-run parameters across nations are homogenous. The pooled mean group estimator often allows homogeneity of the long-run parameters over a single subset of countries or regressors.

To achieve the study's objective, the stock markets in eight African countries (South Africa, Nigeria, Kenya, Ghana, Egypt, Morocco, Tunisia, and Mauritius) used for the study from 1994 to 2018. Notably, the selected countries are informed that they represent over $97 \%$ of the equity market capitalization of Africa, and they represent the five regions in Africa. The data upon which this research is based was sourced from the World Development Indicators (2018).

\section{EMPIRICAL RESULTS}

Table 1 provides the estimated results of the PMG regression model. The results from the pooled mean group (PMG) indicate that macroeconomic variables do have severe implications for stock prices in Africa. Among these economic variables, the prime driver of stock market development, in the long run, is credit to the private sector, external reserves, and inflation, which were all positively related to stock market development in the long run. Although trade openness and foreign direct investment were found to directly correlate with stock market development in Africa, they were not statistically significant in the long run. Similarly, broad money supply and the lending rate were found to have an inverse but insignificant relationship with stock market development in Africa. One possible reason for this is that many of Africa's stock markets are still underdeveloped with little margin trading and secured lending business.

However, in the short run, the most important factors that determine stock market development in Africa are income (measured by per capita GDP) and trade openness. While income was found to vary directly with stock market development, trade openness was found to have an inverse relationship with stock market development. An increased income per capita implies that, on average, people have an increased capacity to invest in the stock market, thereby increasing the demand for equities. It may also translate to increased demand for the listed firms' goods and services, which increases profitability and, as such, better per-share earnings, better dividends, and stock market valuation. The negative sign of trade openness reflects that the current terms of trade in goods and services at the international market do not favor African countries. As such, the more open they become, the higher the tendency that trade would hurt their economies and stock markets. More so, in the short run, change in credit to the private sector, foreign direct investment, external reserve, and lending interest rate were found to be insignificant factors. Simultaneously, broad money sup-

Table 1. Pooled mean group estimator result

Source: Authors' estimations.

\begin{tabular}{|c|c|c|}
\hline \multirow{3}{*}{ D.Market Cap } & \multicolumn{2}{|c|}{ Pooled mean group } \\
\hline & Long-run & Short-run \\
\hline & Coefficient (Z-score) & Coefficient (Z-score) \\
\hline Credit to Private Sector & $0.559(1.84)^{*}$ & $0.522(1.13)$ \\
\hline FDI & $0.004(0.06)$ & $-0.017(-0.25)$ \\
\hline External Reserves & $0.853(4.47) * * *$ & $-0.156(-1.47)$ \\
\hline M2 & $-0.44(-1.08)$ & $-0.143(-0.19)$ \\
\hline Trade Openness & $0.373(1.16)$ & $-0.883(-2.51) * * *$ \\
\hline Inflation *** & $0.03(4.18) * * *$ & $0.016(1.38)$ \\
\hline Per Capita GDP & $-0.223(-0.55)$ & $1.484(1.97)^{* *}$ \\
\hline Lending rate & $-0.012(-1)$ & $0.008(0.2)$ \\
\hline Error Correction (EC) & & $-0.515(-4.2) * * *$ \\
\hline Constant & & $-3.246(-4.17) * * *$ \\
\hline
\end{tabular}

Note: $*, * *$, and $* * *$ indicate significance at $10 \%, 5 \%$, and $1 \%$, respectively. These estimations were done using (xtpmg) approach in Stata. The first set of panels shows the long-run results, while the second set of panels shows the short-run results. 
Table 2. Country-specific pooled mean group estimator short-run result

\begin{tabular}{|c|c|c|c|c|c|}
\hline \multicolumn{3}{|c|}{ Egypt PMG short-run } & \multicolumn{3}{|c|}{ Ghana 2 PMG short-run } \\
\hline Error Correction (EC) $* * *$ & -0.479 & -3.81 & Error Correction $(\mathrm{EC}) * * *$ & -0.248 & -2.52 \\
\hline$\Delta$ Credit to Private Sector $* * *$ & -2.349 & -2.68 & $\Delta$ Credit to Private Sector * & 0.96 & 1.69 \\
\hline$\triangle \mathrm{FDI} * * *$ & 0.226 & 4.08 & $\triangle \mathrm{FDI}$ & 0.087 & 0.53 \\
\hline$\Delta$ External Reserves & -0.6 & -1.55 & $\Delta$ External Reserves & -0.12 & -0.52 \\
\hline$\Delta \mathrm{M} 2 * *$ & 3.336 & 2.11 & $\triangle M 2$ & -0.588 & -0.63 \\
\hline$\Delta$ Trade Openness & 0.633 & 1.13 & $\Delta$ Trade Openness & -134 & -0.19 \\
\hline$\Delta$ Inflation & -0.004 & -0.48 & $\Delta$ Inflation & -0.001 & -0.07 \\
\hline$\triangle$ Per Capita GDP & -1.153 & -1.13 & $\triangle$ Per Capita GDP & 0.458 & 0.78 \\
\hline$\Delta$ Lending rate ${ }^{*}$ & -0.094 & -1.6 & $\Delta$ Lending rate & -0.002 & -0.28 \\
\hline Constant & -2.99 & -1.31 & Constant & -1.75 & -1.43 \\
\hline \multicolumn{3}{|c|}{ Kenya PMG short-run } & \multicolumn{3}{|c|}{ Mauritius 4 PMG short-run } \\
\hline Error Correction (EC) $* * *$ & -0.794 & -4.36 & Error Correction $(\mathrm{EC})^{* * *}$ & -0.371 & -2.35 \\
\hline$\Delta$ Credit to Private Sector & 0.163 & 0.14 & $\Delta$ Credit to Private Sector & 0.778 & 1.6 \\
\hline$\Delta \mathrm{FDI}$ & 0.032 & 0.72 & $\Delta \mathrm{FDI}$ & 0.059 & 1.24 \\
\hline$\Delta$ External Reserves & 0.048 & 0.16 & $\Delta$ External Reserves & -0.313 & -0.76 \\
\hline$\triangle \mathrm{M} 2$ & 0.831 & 0.53 & $\triangle \mathrm{M} 2 * * *$ & -3.393 & -2.71 \\
\hline$\Delta$ Trade Openness & -0.94 & -1.48 & $\Delta$ Trade Openness & -1.384 & -1.31 \\
\hline$\Delta$ Inflation & -0.006 & -0.8 & $\Delta$ Inflation & -0.005 & -0.19 \\
\hline$\triangle$ Per Capita GDP $* * *$ & 2.297 & 2.4 & $\triangle$ Per Capita GDP $* * *$ & 4.616 & 2.48 \\
\hline$\Delta$ Lending rate ${ }^{*}$ & -0.037 & -1.79 & $\Delta$ Lending rate $* * *$ & 0.058 & 2.59 \\
\hline Constant & -4.83 & -1.47 & Constant & -1.878 & -1.22 \\
\hline \multicolumn{3}{|c|}{ Morocco PMG short-run } & \multicolumn{3}{|c|}{ Nigeria 6 PMG short-run } \\
\hline Error Correction (EC) $* * *$ & -1.093 & -5.43 & Error Correction $(\mathrm{EC}) * * *$ & -0.789 & -6.76 \\
\hline$\Delta$ Credit to Private Sector & 1.686 & 1.5 & $\Delta$ Credit to Private Sector $* *$ & 0.898 & 2.22 \\
\hline$\triangle \mathrm{FDI}$ & -0.007 & -0.04 & $\Delta \mathrm{FDI} * * *$ & -0.451 & -3.99 \\
\hline$\Delta$ External Reserves & -0.524 & -0.68 & $\Delta$ External Reserves & 0.076 & 0.36 \\
\hline$\triangle \mathrm{M} 2$ & -1.428 & -0.43 & $\triangle M_{2}$ & -0.04 & -0.07 \\
\hline$\Delta$ Trade Openness & -2.685 & -1.5 & $\triangle$ Trade Openness * & -0.415 & -1.62 \\
\hline$\Delta$ Inflation & 0.068 & 0.79 & $\Delta$ Inflation $* * *$ & -0.019 & -2.83 \\
\hline$\triangle$ Per Capita GDP $* * *$ & 4.069 & 1.55 & $\triangle$ Per Capita GDP * & -0.957 & -1.61 \\
\hline$\Delta$ Lending rate $*$ & 0.25 & 1.08 & $\Delta$ Lending rate ${ }^{* * *}$ & -0.124 & -3.34 \\
\hline Constant & -6.552 & -1.29 & Constant & -5.628 & -1.66 \\
\hline \multicolumn{3}{|c|}{ South Africa PMG short-run } & \multicolumn{3}{|c|}{ Tunisia PMG short-run } \\
\hline Error Correction (EC) & -0.047 & -0.47 & Error Correction $(E C) * * *$ & -0.303 & -3.41 \\
\hline$\Delta$ Credit to Private Sector $* * *$ & 1.841 & 2.78 & $\Delta$ Credit to Private Sector & 0.196 & 0.34 \\
\hline$\triangle \mathrm{FDI} *$ & -0.06 & -1.67 & $\triangle \mathrm{FDI}$ & -0.023 & -0.41 \\
\hline$\Delta$ External Reserves & 0.253 & 1.52 & $\triangle$ External Reserves & -0.065 & -0.21 \\
\hline$\Delta \mathrm{M}_{2}$ & -1.442 & -1.1 & $\triangle \mathrm{M} 2$ & 1.583 & 1.55 \\
\hline$\Delta$ Trade Openness *** & -1.427 & -2.46 & $\Delta$ Trade Openness & -0.712 & -1.21 \\
\hline$\Delta$ Inflation & 0.045 & 1.51 & $\Delta$ Inflation & 0.046 & 0.67 \\
\hline$\triangle$ Per Capita GDP & 1.813 & 1.35 & $\triangle$ Per Capita GDP & 0.729 & 0.63 \\
\hline$\Delta$ Lending rate & 0.01 & 0.32 & $\Delta$ Lending rate & 0.004 & 0.05 \\
\hline Constant & -0.15 & -0.3 & Constant * & -2.197 & -1.64 \\
\hline
\end{tabular}

ply and inflation were significant, explaining stock market development in Africa.

Table 2 provides the estimated short-run results of the PMG regression model for the eight selected countries in Africa. The results from the pooled mean group (PMG) indicate that macroeconomic variables do have serious implications for stock prices in Africa. Among these economic variables, a prime driver of stock market development in the short run is credit to the private sector, which presented a significant nexus with stock market development for four countries (Egypt, Ghana, Nigeria, and South Africa). Furthermore, among the four countries with significant outcomes, a negative result was observed in Egypt, while the others reported a positive effect. Per capita GDP was also a signif- 
icant driver in three countries, namely Kenya, Mauritius, and Morocco, which all presented positive impacts and lending rates for five out of eight countries, namely, Egypt, Kenya, Mauritius, Morocco, and Nigeria. Notably, negative results were found in Egypt, Kenya, and Nigeria. Trade openness was also observed to be significant for two out of eight selected countries (Mauritius and South Africa). Also, the error correction term was significant and tended towards the upper boundary ( 0 and 1 ) for seven out of eight countries. As specified by theory, the error correction values imply a relatively high probability of reliance on the short-run values.

The stock market plays a critical role in the economy of the countries. Alongside the banks, pension funds, and the insurance sector, they constitute the "heart of the financial system" of a country. It provides a mechanism for transforming savings from surplus economic units into financing for economic agents in need of long-term capital. According to the World Federation of Exchanges (2017), efficient stock markets promote growth in the economy by encouraging the deployment of financial assets by putting together people who require long-term funds to innovate and expand with people with resources to invest. Another primary role of the stock market is that it provides an avenue for an orderly and seamless transfer of shares of companies among shareholders. The stock market also promotes financial system efficiency by providing competition to other classes of financial instruments like bonds, treasury bills, commercial papers, and certificates of deposits. It provides investment outlay to large institutional investors and small retail investors by providing them with the opportunity to invest in not only shares but also derivatives, exchange-traded products (ETPs), collective or pooled investment schemes like mutual funds, unit trust, and real estate investment trust, as well as stock options and futures.

Stock markets also promote good governance in business practices (World Federation of Exchanges, 2017). It supports effective management of companies by providing a framework for corporate governance and ensuring that corporate entities are run in the best interest of investors and society. It enables the companies to tap into the benefits of financial globalization by providing them with diversified foreign portfolio investors. It facilitates companies' growth through mergers, acquisitions, and takeovers, thereby offering opportunities to enlarge product lines, improve supply channels, hedge risk, and grow their share of the market.

\section{CONCLUSION}

This research analyzed the macroeconomic drivers of stock market development in Africa. Eight African countries were used for this study, including South Africa, Nigeria, Egypt, Morocco, Tunisia, Ghana, Kenya, and Mauritius, with data spanning 24 years from 1994 to 2018. The research examined how eight macroeconomic factors affect stock market development in Africa using the pooled mean group panel data estimation technique. These macroeconomic variables included per capita GDP, credit to the private sector, external reserve, inflation, lending interest rate, broad money supply, foreign direct investment, external trade. The empirical results showed that credit to the private sector, external reserves, and inflation directly and significantly influence stock market development in Africa in the long run. While income level (measured by per capita GDP) and trade openness were also critical economic issues to consider, their effects were most relevant in the short run. These research findings underscore the significance of a well-developed private sector for stock market development as the stock market is primarily a private sector driven activity. It also emphasizes that since external reserve could have implications for the domestic exchange rate, investors consider it an essential factor in investment decisions in Africa. Also, the level of income in African countries would have a severe consequence for the population's ability to save and undertake investment in the capital market. 


\section{RECOMMENDATIONS}

Based on the study's findings, the study recommends that economic policy boost stock market activities in Africa should focus on developing the private sector through increased credit opportunities to the private sector. A more robust private sector means that more companies will have the capacity to list in African markets, and market liquidity will be increased through the rise in security lending and margin trading activities. The study also recommends using prudent foreign reserve management techniques that would give both local and international investors' confidence in the stability of the currency in which equity assets in African countries are based. Improvement in capital market activities in Africa could also come from economic policies that increase the income of the population, which boosts their capacity to save and thus invest in African stock markets.

\section{AUTHOR CONTRIBUTIONS}

Conceptualization: Paul Uzum, Ailemen Ochei Ikpefan, Alexander Ehimare Omankhanlen.

Data curation: Jeremiah Ogaga Ejemeyovwi.

Investigation: Paul Uzum, Benjamin Ighodalo Ehikioya.

Methodology: Jeremiah Ogaga Ejemeyovwi.

Project administration: Ailemen Ochei Ikpefan, Alexander Ehimare Omankhanlen, Jeremiah Ogaga

Ejemeyovwi.

Resources: Benjamin Ighodalo Ehikioya.

Software: Jeremiah Ogaga Ejemeyovwi, Benjamin Ighodalo Ehikioya.

Supervision: Ailemen Ochei Ikpefan, Alexander Ehimare Omankhanlen.

Validation: Paul Uzum, Jeremiah Ogaga Ejemeyovwi.

Visualization: Jeremiah Ogaga Ejemeyovwi, Benjamin Ighodalo Ehikioya.

Writing - original draft: Paul Uzum.

Writing - review \& editing: Ailemen Ochei Ikpefan, Alexander Ehimare Omankhanlen, Jeremiah Ogaga Ejemeyovwi.

\section{REFERENCES}

1. Agyapong, D., \& Badjabeng, K. A. (2018). External Debt Stock, Foreign Direct Investment and Financial Development Evidence from African Economies. Journal of Asian Business and Economic Studies, 27(1), 81-98. https://doi. org/10.1108/JABES-11-2018-0087

2. Ayaydın, H., Hayaloğlu, P., \& Baltac1, N. (2013). Hisse Senedi Piyasasının Gelişmesinin Makroekonomikve Kurumsal Belirleyicileri Üzerine Bir Araștırma: Panel Veri Analizi. The Journal of Academic Social Science Studies, 6(4). Retrieved from https://www.researchgate. net/publication/297356810_Hisse_ Senedi_Piyasasinin_Gelismesinin_ Makroekonomik_ve_Kurumsal_Belirleyicileri_Uzerine_Bir_ Arastirma_Panel_Veri_Analizi_ The_Journal_of_Academic_So-
cial_Science_Studies_64_125-142 ISSN_2147-2971_Doi_ht

3. Balogun, W. O., Dahalan, J. B., \& Hassan, S. B. (2016). Stock Market Development, Liberalisation and Financial Development in the Selected Sub-Saharan African Countries. Romanian Economic and Business Review, 11(2). Retrieved from https://ideas. repec.org/a/rau/journl/v11y2016i2p52-65.html

4. Bayar, Y. (2016). Macroeconomic Determinants of Stock Market Development: Evidence from Borsa, Istanbul. Financial Studies, 1. Retrieved from https://ideas. repec.org/a/vls/finstu/v20y2016ilp69-89.html

5. Bello, H. T., Ayadi, F., Osabuohien, E. S., Ejemeyovwi, J. O., \& Okafor, V. (2020). Economic
Analysis of Growth Finance and Liquid Liabilities in Nigeria. Investment Management and Financial Innovations, 17(3), 387396. http://dx.doi.org/10.21511/ imfi.17(3).2020.29

6. Billmeier, A., \& Massa, I. (2009). What Drives Stock Market Development in Emerging Markets: Institutions, Remittances or Natural Resources? Emerging Markets Review, 10. https://doi. org/10.1016/j.ememar.2008.10.005

7. Calderon-Rossell, R. J. (1991). The Determinants of Stock Market Growth. In S. Ghon Rhee \& Rosita P. Chang (Eds.), Pacific Basin Capital Markets Research Proceeding. Bangkok-Thailand: Second Annual Pacific Basin Finance Conference.

8. Ejemeyovwi, J. O., Osabuohien, E. S., \& Osabuohien, R. (2018). 
Investment in Technology and Human Capital Development in ECOWAS International Journal Economics and Business Research, 15(4), 463-474. Retrieved from https://covenantuniversity.edu.ng/ content/download/59856/404829/ file/IJBER_ICT+Adoption+and + Inclusive + Growth + in + ECOW AS_published.pdf

9. Ejemeyovwi, J. O. Osabuohien, E. S. Bowale, E. K. Abuh, O., Adedoyin, J. P., \& Ayanda, B. (2019). Information and Communication Technology Adoption and Innovation for Sustainable Entrepreneurship. Journal of Physics: Conference Series, 1378(2), 022085.

Retrieved from https://iopscience.iop.org/article/10.1088/1742-6596/1378/2/022085

10. Jamaludin, C. N., Ismail, S., \& Manaf, S. A. (2017). Macroeconomic Variables and Stock Market Returns: Panel Analysis from Selected ASEAN Countries. International Journal of Economics and Financial Issues, 7(1). Retrieved from https://www. econjournals.com/index.php/ijefi/ article/view/3110

11. Kabuga, N. A. (2018). Budget Deficits and Stock Market Performance in Selected African Countries: A Dynamic Panel Estimation Approach. UMYUK Journal of Economics and Development (UJED), 1(1). Retrieved from https://www. researchgate.net/profile/Nura_Kabuga2/publication/323538477 Budget_Deficits_and_Stock_Market_Performance_in_Selected_African_Countries_A_Dynamic_Panel_estimation_Approach/ links/5a9ac694aca2721e3f300328/ Budget-Deficits-and-Stock-Mar-
ket-Performance-in-Selected-African-Countries-A-Dynamic-Panelestimation-Approach.pdf

12. Khan, S. (2017). Macroeconomic Determinants of Stock market Development of South Asian Countries (MSc Thesis). Capital University of Science and Technology, Islamabad.

13. Matadeen, S. J. (2017). The Macroeconomic Determinants of Stock Market Development from an African Perspective. Theoretical Economics, 7. Retrieved from https://www.scirp.org/ journal/paperinformation. aspx?paperid $=80606$

14. Mroua, M., \& Trabelsi, L. (2019). Causality and Dynamic Relationships Between Exchange Rate and Stock Market Indices in BRICS Countries. Panel/ GMM and ARDL Analyses. Journal of Economics, Finance and Administrative Science, 1 . Retrieved from https://www. emerald.com/insight/content/ doi/10.1108/JEFAS-04-2019-0054/ full/pdf

15. Nasimi, R. N., Nasimi, A. N., \& Khurshid, S. (2018). Stock Returns Under Political and Macroeconomic Instabilities: An Empirical Analysis from United Kingdom. Research Journal of Finance and Accounting, 9(15). Retrieved from https://iiste.org/ Journals/index.php/RJFA/article/ view/43832

16. Pesaran, M. H., Shin, Y., \& Smith, R. P. (1999). Pooled Mean Group Estimation of Dynamic Heterogeneous Panels. Journal of the American Statistical Association, 94(446). Retrieved from https://www.jstor.org/ stable $/ 2670182$ ?seq $=1$

17. Rasiah, R., Habibullah, M., \& Hamid, B. (2017). A Dynamic Heterogeneous Panel Estimation of the Impact of Income, Inflation and Happiness on Stock Returns. Global Economy and Finance Journal, 9(1). Retrieved from https://www.researchgate.net/ publication/301890811_A_Dynamic_Heterogeneous_Panel_Estimation_of_the_Impact_of_Income_Inflation_and_Happiness_ on_Stock_Returns

18. Tsaurai, K. (2018). What are the Determinants of Stock Market Development in Emerging Markets? Academy of Accounting and Financial Studies Journal, 22(2). Retrieved from https:// www.abacademies.org/articles/ what-are-the-determinants-ofstock-market-development-inemerging-markets-7135.html

19. World Bank. (2020). World Development Indicators. Retrieved from http://data.worldbank.org/ data-catalog/world-developmentindicators (accessed on 7/03/2020).

20. World Federation of Exchanges. (2018). The Role of Stock Exchanges in Fostering Economic Growth and Sustainable Development (UNCTAD World Investment Report, 2017). Retrieved from https://unctad.org/ system/files/official-document/ WFE_UNCTAD_2017_en.pdf

21. World Federation of Exchanges. (2018). What Attracts International Investors to Emerging Markets. Retrieved from https:// www.world-exchanges.org/ our-work/articles/what-attractsinternational-investors-emergingmarkets 